\title{
ANALISIS FAKTOR-FAKTOR YANG MEMPENGARUHI KUALITAS LAPORAN KEUANGAN PEMERINTAH DAERAH (Studi Pada Pemerintah Kabupaten Pasaman Barat)
}

\author{
Rizki Afri Mulia \\ Dosen Program Studi Administrasi Negara \\ Sekolah Tinggi Ilmu Sosial dan Politik Imam Bonjol Padang \\ Email : rizkiafri_mulia@yahoo.com
}

\begin{abstract}
ABSTRAK
Bentuk laporan pertanggungjawaban atas pengelolaan keuangan daerah selama satu tahun anggaran adalah dalam bentuk Laporan Keuangan Pemerintah Daerah (LKPD). Laporan keuangan pemerintah daerah harus mengikuti Standar Akuntansi Pemerintahan sesuai Peraturan Pemerintah No.24 Tahun 2005. Penelitian ini bertujuan untuk memberikan bukti bahwa : 1) Untuk memberikan bukti empiris dan menganalisis pengaruh kompetensi Sumber Daya Manusia (SDM) terhadap kualitas laporan keuangan pemerintah daerah Pasaman Barat secara signifikan. 2) Untuk memberikan bukti empiris dan menganalisis pengaruh Sistem Pengendalian Intern terhadap kualitas laporan keuangan pemerintah daerah Pasaman Barat secara signifikan.

Pengumpulan data dilakukan dengan metode survei dengan kuesioner. Teknik analisa data yang digunakan dalam penelitian ini adalah analisis deskriptif dan kuantitatif. Data yang dikumpulkan merupakan data primer dan sekunder yang dapat digolongkan sebagai variabel bebas dan variabel terikat. Kompetensi SDM dan Sistem Pengendalian Intern (variabel pengaruh), dan Kualitas Laporan Keuangan Pemerintah Daerah Kabupaten Pasaman Barat (variabel terpengaruh). Pengujian hipotesis dalam penelitian ini menggunakan uji regresi linier berganda.

Berdasarkan hasil penelitian diketahui bahwa : 1) Terdapat pengaruh positif dan signifikan antara Kompetensi SDM terhadap Kualitas Laporan Keuangan Pemerintah Daerah Kabupaten Pasaman Barat didapat $\mathrm{T}_{\text {hitung }}$ dimana 3,249 dengan signifikansi 0,002 dimana $0,002<0,05$. 2) Terdapat pengaruh positif dan signifikan antara Sistem Pengendalian Inter terhadap dan Laporan Keuangan Pemerintah Daerah Kabupaten Pasaman Barat didapat $\mathrm{T}_{\text {hitung }}$ dimana 4,524 dengan signifikansi $0,000<0,05$.
\end{abstract}

Kata kunci : Kompetensi SDM, Sistem Pengendalian Intern, Kualitas Laporan Keuangan.

\section{A. PENDAhuluan}

Dalam pengelolaan keuangan, pemerintah melakukan reformasi dengan mengeluarkan Undang-Undang Nomor 17 Tahun 2003 tentang Keuangan Negara yang mensyaratkan bentuk dan isi laporan pertanggungjawaban 
pelaksanaan Anggaran Pendapatan dan Belanja Negara (APBN) atau Anggaran Pendapatan dan Belanja Daerah (APBD) yang harus disusun dan disajikan dengan standar akuntansi pemerintahan yang ditetapkan oleh peraturan pemerintah. Pemerintah juga mengeluarkan Undang-Undang No. 32 Tahun 2004 tentang Pemerintahan Daerah.

Berdasarkan Undang-Undang Nomor 17 Tahun 2003 dan Undangundang No. 32 Tahun 2004 tersebut, pemerintah mengeluarkan Peraturan Pemerintah No. 24 Tahun 2005 tentang Standar Akuntansi Pemerintahan (SAP). SAP merupakan prinsip-prinsip akuntansi yang ditetapkan dalam menyusun dan menyajikan laporan keuangan pemerintah. Tujuan penting reformasi akuntansi dan administrasi sektor publik adalah akuntabilitas dan transparansi pengelolaan keuangan pemerintah pusat maupun daerah (Badjuri dan Trihapsari, 2004).

Bentuk laporan pertanggungjawaban atas pengelolaan keuangan daerah selama satu tahun anggaran adalah dalam bentuk Laporan Keuangan Pemerintah Daerah (LKPD). Laporan keuangan pemerintah daerah harus mengikuti Standar Akuntansi Pemerintahan sesuai Peraturan Pemerintah No.24 Tahun 2005. Tujuan diberlakukannya hal tersebut adalah agar lebih accountable dan semakin diperlukannya peningkatan kualitas laporan keuangan. Kualitas laporan keuangan pemerintah sangat dipengaruhi oleh faktor kepatuhan terhadap standar akuntansi, kapabilitas sumber daya manusia, serta dukungan sistem akuntansi yang ada. Tidak pula terlepas dinamika perubahan eksternal yang tidak dapat dikendalikan oleh organisasi.

Laporan keuangan pemerintah kemudian disampaikan kepada DPR/DPRD dan masyarakat umum setelah diaudit oleh Badan Pemeriksa Keuangan (BPK). Adapun komponen laporan keuangan yang disampaikan tersebut meliputi Laporan Realisasi Anggaran, Neraca, Laporan Arus Kas, dan Catatan atas Laporan Keuangan. Governmental Accounting Standard Board (1999) dalam Concepts Statement No.1 tentang Objectives of Financial Reporting menyatakan bahwa akuntabilitas merupakan dasar pelaporan keuangan di pemerintahan. Pengelolaan keuangan pemerintah daerah harus dilakukan berdasarkan tata kelola kepemerintahan yang baik (good governance government), yaitu pengelolaan keuangan yang dilakukan secara transparan dan akuntabel, yang memungkinkan para pemakai laporan keuangan untuk dapat mengakses informasi tentang hasilyang dicapai dalam penyelenggaraan pemerintahan daerah.

Laporan keuangan yang dihasilkan oleh pemerintah daerah akan digunakan oleh beberapa pihak yang berkepentingan sebagai dasar untuk pengambilan keputusan. Oleh karena itu, informasi yang terdapat di dalam Laporan Keuangan Pemerintah Daerah (LKPD) harus bermanfaat dan sesuai dengan kebutuhan para pemakai. Huang et al dalam Xu et al. (2003) menyatakan bahwa informasi akan bermanfaat apabila informasi tersebut dapat mendukung pengambilan keputusan dan dapat dipahami oleh para pemakai. Oleh karena itu, pemerintah daerah wajib memperhatikan informasi yang disajikan dalam laporan keuangan untuk keperluan perencanaan, pengendalian, dan pengambilan keputusan. 
Apabila informasi yang terdapat di dalam Laporan Keuangan Pemerintah Daerah memenuhi kriteria karakteristik kualitatif laporan keuangan pemerintah seperti yang disyaratkan dalam Peraturan Pemerintah Nomor 24 Tahun 2005, berarti pemerintah daerah mampu mewujudkan transparansi dan akuntabilitas dalam pengelolaan keuangan daerah. Informasi yang terkandung di dalam laporan keuangan yang dihasilkan oleh pemerintah daerah harus sesuai dengan kriteria nilai informasi yang disyaratkan oleh peraturan perundangundangan. Apabila tidak sesuai dengan perundang-undangan, maka akan mengakibatkan kerugian daerah, potensi kekurangan daerah, kekurangan penerimaan, kelemahan administrasi, ketidak hematan, ketidak efisienan, dan ketidak efektifan.

Salah satu kabupaten yang menjadi pusat perhatian penulis adalah Kabupaten Pasaman Barat. Dimana opini laporan keuangan dari BPK adalah wajar dengan pengecualian (WDP) Pasaman Barat 2013 karena permasalah yang berkaitan dengan (1) kekurangan Kas yang belum diselesaikan oleh bendahara Pengeluaran, (2) Investasi Permanen pada Perusahaan Daerah Mekar Jaya Madani tidak dapat dinilai menggunakan metode ekuitas karena tidak didukung dengan sumber data yang memadai, (3) Saldo Aset tetap pada Neraca per 31 Desember 2013 tidak memiliki data yang akurat dan (4) Pemerintah Kabupaten Pasaman Barat tidak dapat menyajikan nilai kewajiban atas pekerjaan Tahun 2013. (LKPD Pasaman Barat Tahun 2014).

Berdasarkan fenomena-fenomena tersebut, dapat disimpulkan bahwa laporan keuangan yang dihasilkan oleh pemerintah daerah masih belum memenuhi kriteria nilai informasi yang disyaratkan. Mengingat bahwa karakterisktik kualitatif merupakan unsur penting dalam Laporan Keuangan Pemerintah Daerah sebagai dasar pengambilan keputusan, maka peneliti tertarik untuk meneliti faktor apa saja yang dapat mempengaruhi keandalan dan ketepatan waktu pelaporan keuangan pemerintah daerah.

Berdasarkan uraian latar belakang, maka rumusan masalah dalam penelitian inidapat dirumuskan sebagai berikut: 1) Apakah kompetensi Sumber Daya Manusia (SDM) mempengaruhi kualitas laporan keuangan pemerintah daerah Pasaman Barat secara signifikan? 2) Apakah Sistem Pengendalian Intern (SPI) mempengaruhi kualitas laporan keuangan pemerintah daerah Pasaman Barat secara signifikan?

\section{B. KAJIAN TEORI}

\section{Laporan Keuangan}

Laporan keuangan adalah catatan informasi suatu entitas pada suatuperiode akuntansi yang dapat digunakan untuk menggambarkan kinerja entitas tersebut. Laporan keuangan merupakan laporan yang terstruktur mengenai posisi keuangan dan transaksi-transaksi yang dilakukan oleh suatu entitas pelaporan. Laporan keuangan dapat dikatakan sebagai data juga dapat dikatakan sebagai informasi. Data dapat berubah menjadi informasi kalau diubah ke dalam konteks yang memberikan makna (Lillrank, 2003).

Tujuan umum laporan keuangan adalah menyajikan informasi mengenai posisi keuangan, realisasi anggaran, arus kas, dan kinerja 
keuangan suatu entitas pelaporan yang bermanfaat bagi para pengguna dalam membuat dan mengevaluasi keputusan mengenai alokasi sumber daya. Secara spesifik, tujuan pelaporan keuangan pemerintah adalah untuk menyajikan informasi yang berguna untuk pengambilan keputusan dan untuk menunjukkan akuntabilitas entitas pelaporan atas sumber daya yang dipercayakan kepadanya, dengan:

a. Menyediakan informasi mengenai posisi sumber daya ekonomi, kewajiban, dan ekuitas dana pemerintah;

b. Menyediakan informasi mengenai perubahan posisi sumber daya ekonomi, kewajiban, dan ekuitas dana pemerintah;

c. Menyediakan informasi mengenai sumber, alokasi, dan penggunaan sumber daya ekonomi;

d. Menyediakan informasi mengenai ketaatan realisasi terhadap anggarannya;

e. Menyediakan informasi mengenai cara entitas pelaporan mendanai aktivitasnya dan memenuhi kebutuhan kasnya;

f. Menyediakan informasi mengenai potensi pemerintah untuk membiayai penyelenggaraan kegiatan pemerintahan;

g. Menyediakan informasi yang berguna untuk mengevaluasi kemampuan entitas pelaporan dalam mendanai aktivitasnya.

Laporan keuangan untuk tujuan umum juga mempunyai peranan prediktif dan prospektif, menyediakan informasi yang berguna untuk memprediksi besarnya sumber daya yang dibutuhkan untuk operasi yang berkelanjutan, sumber daya yang dihasilkan dari operasi yang berkelanjutan, serta risiko dan ketidakpastian yang terkait. Pelaporan keuangan juga menyajikan informasi bagi pengguna mengenai:

a. Indikasi apakah sumber daya telah diperoleh dan digunakan sesuai dengan anggaran; dan

b. Indikasi apakah sumber daya diperoleh dan digunakan sesuai dengan ketentuan, termasuk batas anggaran yang ditetapkan oleh DPR/DPRD.

Untuk memenuhi tujuan umum ini, laporan keuangan menyediakan informasi mengenai entitas pelaporan dalam hal:

a. Aset;

b. Kewajiban;

c. Ekuitas dana;

d. Pendapatan;

e. Belanja;

f. Transfer;

g. Pembiayaan; dan

h. Arus kas.

Informasi dalam laporan keuangan tersebut relevan untuk memenuhi tujuan laporan keuangan pemerintah, namun tidak dapat sepenuhnya memenuhi tujuan tersebut. Informasi tambahan, termasuk laporan non keuangan, dapat dilaporkan bersama-sama dengan laporan keuangan untuk memberikan gambaran yang lebih komprehensif mengenai aktivitas suatu entitas pelaporan selama satu periode. 


\section{Sumber Daya Manusia}

Widodo (2001) dalam Kharis (2010) menjelaskan kompetensi sumber daya manusia adalah kemampuan sumber daya manusia untuk melaksanakan tugas dan tanggung jawab yang diberikan kepadanya dengan bekal pendidikan, pelatihan, dan pengalaman yang cukup memadai. Wiley (2002) dalam Azhar (2007) mendefinisikan "Sumber daya manusia merupakan pilar penyangga utama sekaligus penggerak roda organisasi dalam usaha mewujudkan visi dan misi serta tujuan dari organisasi tersebut". Sumber daya manusia merupakan salah satu elemen organisasi yang sangat penting, oleh karena itu harus dipastikan bahwa pengelolaan sumber daya manusia dilakukan sebaik mungkin agar mampu memberikan kontribusi secara optimal dalam upaya pencapaian tujuan organisasi.

Dalam pengelolaan keuangan daerah yang baik, SKPD harus memiliki sumber daya manusia yang kompeten, yang didukung dengan latar belakang pendidikan akuntansi, sering mengikuti pendidikan dan pelatihan, dan mempunyai pengalaman dibidang keuangan. Hal tersebut diperlukan untuk menerapkan sistem akuntansi yang ada. Sumber daya manusia (SDM) yang kompeten tersebut akan mampu memahami logika akuntansi dengan baik. Kegagalan sumber daya manusia Pemerintah Daerah dalam memahami dan menerapkan logika akuntansi akan berdampak pada kekeliruan laporan keuangan yang dibuat dan ketidak sesuaian laporan dengan standar yang ditetapkan pemerintah (Warisno,2008).

Analisis kompetensi disusun sebagian besar untuk pengembangan karir, tetapi penentuan tingkat kompetensi dibutuhkan untuk mengetahui efektivitas tingkat kerja yang diharapkan. Keterampilan (skill), pengetahuan (knowledge), dan sikap (attitude) merupakan faktor yang menentukan penilaian terhadap kompetensi sumber daya maunusia dalam menghasilkan tingkat kinerja pada suatu perusahaan.

Hutapea dan Thoha (2008:28) mengungkapkan bahwa ada tiga komponen utama pembentukan kompetensi yaitu pengetahuan yang dimiliki seseorang, kemampuan, dan perilaku individu. Pengetahuan (knowledge) adalah informasi yang dimiliki seseorang karyawan untuk melaksanakan tugas dan tanggung jawabnya sesuai bidang yang digelutinya (tertentu), misalnya bahasa komputer. Pengetahuan karyawan turut menentukan berhasil tidaknya pelaksanaan tugas yang dibebankan kepadanya, karyawan yang mempunyai pengetahuan yang cukup meningkatkan efesiensi perusahaan.

Keterampilan (skill) merupakan suatu upaya untuk melaksanakan tugas dan tanggung jawab yang diberikan perusahaan kepada seseorang karyawan dengan baik dan maksimal, misalnya seorang programer computer. Disamping pengetahuan dan kemampuan karyawan, hal yang paling perlu diperhatikan adalah sikap perilaku karyawan. Sikap (attitude) merupakan pola tingkah laku seseorang karyawan di dalam melaksanakan tugas dan tanggung jawabnya sesuai dengan peraturan perusahaan. Apabila karyawan mempunyai sifat mendukung pencapaian organisasi, maka secara 
otomatis segala tugas yang dibebankan kepadanya akan dilaksanakan sebaik-baiknya.

Kompetensi knowledge, skill, dan attitude cenderung lebih nyata (visible) dan relatif berada di permukaan ( ujung ) sebagai karakteristik yang dimiliki manusia. Dengan demikian dapat disimpulkan bahwa kompetensi adalah kemampuan dan kemauan untuk melakukan sebuah tugas dengan kinerja yang efektif dan efisien untuk mencapai tujuan perusahaan.

\section{Sistem Pengendalian Intern}

$\mathrm{Xu}$, et al. (2003) menjelaskan bahwa interaksi antara orang dan sistem serta implementasi sistem merupakan faktor penting yang mempengaruhi kualitas dari sebuah informasi. Keandalan sistem harus juga didukung oleh keandalan sumber daya manusia. Namun sistem yang sudah berjalan harus dikontrol agar tetap dapat berjalan baik.

Pengendalian intern yang didefinisikan oleh COSO (dalam Sawyer et al, 2005) adalah:

"Internal control is a process, effected by an entity's board of directors, management and other personel, designed to provide reasonable assurance regarding the achievement of objectives in the following categories:

a. Effectiveness and efficiency of operations

b. Reliability of financial reporting

c. Compliance with applicable laws and regulations."

Tujuan yang pertama adalah menekankan pada tujuan dasar dalam setiap organisasi, mencakup kinerja, profitabilitas dan pengamanan sumber daya. Kedua adalah menyangkut kehandalan laporan organisasi. Terakhir adalah berkaitan dengan kepatuhan terhadap hukum dan regulasi dimana organisasi itu berada.

Sistem pengendalian intern bukan hal baru dalam pemerintahan. Petrovitset al. (2011) menyatakan:

Internal control is broadly defined as the process put in place by management to provide reasonable assurance regarding the achievement of effective and efficient operations, reliable financial reporting, and compliance with laws and regulations.

PP Nomor 60 Tahun 2008 mendefinisikan pengendalian intern adalah proses yang integral pada tindakan dan kegiatan yang dilakukan secara terus menerus oleh pimpinan dan seluruh pegawai untuk memberikan keyakinan memadai atas tercapainya tujuan organisasi melalui keggiatan yang efektif dan efisien, keandalan pelaporan keuangan, pemgamanan aset negara, dan ketaatan terhadap peraturan perundang-undangan.

SPI merupakan kegiatan pengendalian terutama atas pengelolaan sistem informasi yang bertujuan untuk memastikan akurasi dan kelengkapan informasi. Kegiatan pengendalian atas pengelolaan informasi meliputi:

a. Pengendalian umum

Pengendalian ini meliputi pengamanan sistem informasi, pengendalian atas akses, pengendalian atas pengembangan dan perubahan perangkat 
lunak aplikasi, pengendalian atas perangkat lunak sistem, pemisaan tugas, dan kontinuitas pelayanan.

b. Pengendalian aplikasi

Pengendalian ini meliputi pengendalian otorisasi, pengendalian kelengkapan, pengendalian akurasi, dan pengendalian terhadap keandalan pemrosesan dan file data.

\section{Hipotesis Penelitian}

1. Kompetensi sumber daya manusia berpengaruh positif dan signifikan terhadap kualitas laporan keuangan

2. Sistem pengendalian intern berpengaruh positif dan signifikan terhadap kualitas laporan keuangan

3. Faktor eksternal berpengaruh signifikan terhadap kualitas laporan keuangan

4. Sumber daya manusia, Sistem pengendalian intern, dan faktor eksternal berpengaruh secara simultan dan signifikan terhadap laporan keuangan

\section{HASIL PENELITIAN}

\section{Analisis Deskriptif}

Kompetensi sumber daya manusia dilihat dari 3 indikator seperti pengetahuan dengan skor mean 4,39. Dapat diartikan bahwa, pengetahuan karyawan tentang teori yang berkaitan dengan laporan keuangan bisa dikatakan kurang baik karena hampir dari sebagian pegawai atau sekitas $59,09 \%$ merasa kurang paham dan masih ragu-ragu dengan teori yang berkaitan dengan laporan keuangan. Sedangkan pada tingkat pemahaman pagawai tentang aturan laporan keuangan bisa dikatakan bahwa pegawai cukup mengerti tentang aturan laporan keuangan karena hal ini bisa dilihat sekitar 50\% pegawai paham tentang aturan laporan keuangan.

Pengendalian intern dilihat dari 5 indikator seperti lingkungan pengendalian dengan skor mean 4,37. Hal ini dapat diartikan bahwa, pembuatan laporan keuangan yang diikuti pegawai sesuai dengan standar kode etik yang berlaku di instansi dan dilakukan dengan kerja sama sehingga dalam pembuatan laporan keuangan jelas tanggung jawab dan pembagian tugasnya dan dapat mengurangi risiko pelanggaran terhadap sistem dan prosedur akuntansi dalam pembuatan laporan keuangan.

Kualitas laporan keuangan dilihat dari 4 indikator seperti indikator Relevan dengan skor mean 4,14. Hal ini dapat diartikan bahwa, dalam pembuatan laporan keuangan memprediksi kondisi keuangan masa lalu dan mampu memprediksi kondisi keungan masa datang sehingga dapat berpengaruh dan berguna dalam pengambilan keputusan yang disajikan secara lengkap, mencakup semua informasi akuntansi. Pada indikator andal dengan skor mean 3,85 dengan artian laporan keuangan harus buat disajikan secara jujur, tidak dikurang-kurangi dan tidak pula ditambah-tambahkan sesuai dengan fakta di lapangan dan haru diverifikasi agar bebas dari pengertian yang menyesatkan dan kesalahan material.

\section{Uji Asumsi Klasik}

a. Uji Normalitas 
Uji normalitas dilakukan untuk mengetahui apakah data berasal dari populasi yang berdistribusi normal atau tidak. Uji normalitas dilakukan dengan menggunakan uji Kolmogorov-Smirnov. Apabila nilai Asymp. Sig (2-tailed) lebih besar dari > 0,05 maka dapat disimpulkan bahwa data terdistribusi secara normal. Untuk lebih jelasnya perhatikan tabel dibawah:

Tabel 1. Uji Normalitas

\begin{tabular}{c|c|c|c}
\hline \hline No & Variabel & Nilai Sig. & Keterangan \\
\hline 1 & $\begin{array}{c}\text { Kompetensi Sumber Daya } \\
\text { Manusia }\left(\mathrm{X}_{1}\right)\end{array}$ & 0,200 & Normal \\
\hline 2 & $\begin{array}{c}\text { Sistem Pengendalian Intern } \\
\left(\mathrm{X}_{2}\right)\end{array}$ & 0,200 & Normal \\
\hline 3 & $\begin{array}{c}\text { Kualitas Laporan Keuangan } \\
(\mathrm{Y})\end{array}$ & 0,200 & Normal \\
\hline \hline
\end{tabular}

Sumber : Hasil Penelitian 2017

Dari tabel di atas dapat diketahui bahwa nilai signifikansi lebih besar dari 0,05. Karena signifikansi lebih dari 0,05, maka nilai masing-masing variabel tersebut telah berdistribusi normal.

b. Uji Linearitas

Uji linearitas bertujuan untuk mengetahui apakah dua variabel mempunyai hubungan yang linear atau tidak secara signifikan. Uji ini biasanya digunakan sebagai prasyarat dalam analisis korelasi atau regresi linear. Dasar pengambilan keputusan dalam uji linear adalah :

1) Jika nilai probalititas $>0,05$ maka hubungan antara variabel bebas dengan variabel terikat adalah linear.

2) Jika nilai probalititas $<0,05$ maka hubungan antara variabel bebas dengan variabel terikat adalah tidak linear.

Untuk dapat memperjelas tentan uji linearitas dapat dilihat pada tabel uji linearitas berikut :

Tabel 2. Hasil Uji Linearitas

\begin{tabular}{l|c|c|c|c|c}
\hline \multicolumn{1}{c|}{ Variabel } & Fhitung & Ftabel & Sig. & Batar Sig. & Keterangan \\
\hline $\begin{array}{l}\text { Linearitas Antara Kompetensi SDM (X) } \\
\text { dan Kualitas Laporan Keuangan (Y) }\end{array}$ & 0,378 & 2,114 & 0,955 & 0,05 & Linear \\
\hline $\begin{array}{l}\text { Linearitas Antara Sistem Pengendalian } \\
\begin{array}{l}\text { Intern (X) dan Kualitas Laporan } \\
\text { Keuangan (Y) }\end{array}\end{array}$ & 1,298 & 2,084 & 0,278 & 0,05 & Linear \\
\hline
\end{tabular}

Sumber : Hasil Penelitian 2017

Dari hasil tabel di atas hasil uji lineritas antara variabel Kompetensi SDM (X1) dan Kualitas Laporan Kuangan (Y) diperoleh nilai Fhitung $=0,378<$ Ftabel 2,114 di dapat dari df 11.31 dan nilai probabilitas = 0,955>0,05, maka dapat disimpulkan bahwa antara variabel Kompetensi 
SDM (X1) dengan Kualitas Laporan Kuangan (Y) mempunyai hubungan yang linear. Selanjutnya, hasil uji lineritas antara variabel Sistem Pendalian Intern (X2) dan Kualitas Laporan Kuangan (Y) diperoleh nilai Fhitung $=1,298<$ Ftabel 2,084 di dapat dari df 21.21 dan nilai probabilitas $=0,278>0,05$, maka dapat disimpulkan bahwa antara variabel Sistem Pengendalian Intern (X2) dengan Kualitas Laporan Kuangan (Y) mempunyai hubungan yang linear.

c. Uji Multikolinearitas

Uji multikolinieritas bertujuan untuk menguji apakah model regresi ditemukan adanya korelasi di antara variabel bebas. Jika variabel bebas saling berkorelasi, maka variabel-variabel ini tidak ortogonal. Variabel ortogonal adalah variabel bebas yang nilai korelasi antar sesama variabel bebas sama dengan nol. Untuk mendeteksi ada atau tidaknya multikolinieritas di dalam model regresi adalah sebagai berikut :

Tabel 3. Hasil Uji Multikolinearitas

\begin{tabular}{c|l|c|c|c|c}
\hline \hline No & \multicolumn{1}{|c|}{ Variabel } & Nilai VIF & Toleransi & Batas VIF & Keterangan \\
\hline 1 & Kompetensi SDM $\left(\mathrm{X}_{1}\right)$ & 1,102 & 0,907 & 10 & Tidak Terjadi Multikolinearitas \\
\hline 2 & $\begin{array}{l}\text { Sistem Pengendalian } \\
\text { Intern }\left(\mathrm{X}_{2}\right)\end{array}$ & 1,076 & 0,930 & 10 & Tidak Terjadi Multikolinearitas \\
\hline
\end{tabular}

Sumber : Hasil Penelitian 2017

Hasil perhitungan nilai toleransi yang menunjukkan tidak ada variabel bebas yang memiliki nilai tolerance kurang dari $10 \%$ yang berarti tidak ada korelasi antar variabel bebas yang nilainya lebih dari 90\%. Hasil perhitungan nilai variance inflation factor (VIF) juga menunjukkan hal yang sama tidak ada satu variabel bebas yang memiliki nilai VIF lebih dari 10. Jadi dapat disimpulkan bahwa tidak ada multikolinieritas antar variabel bebas dalam model regresi.

d. Uji Heterokedastisitas

Uji heterokedastisitas digunakan untuk menguji apakah terjadi ketidaksamaan varians dari residual satu pengamatan ke pengamatan lain. Apabila terjadi heterokedastisitas, hal ini menunjukkan varians residual tidak sama atau tetap sehingga penggunaan regresi menjadi tidak efesien. Model regresi yang baik adalah homokedastisitas atau bebeas dari gejala heterokedastisitas. Uji heterokedastisitas dapat dilakukan dengan metode korelasi spearman. Pada dasarnya uji heterokedastisitas dilakukan untuk mengetahui apakah antar predictor mempunyai pengaruh yang signifikan dengan nilai residualnya. Residual yang normal adalah yang memiliki nilai signifikan >0,05. Untuk lebih jelasnya dapat dijelaskan pada tabel berikut :

Tabel 4. Uji Heterokedastisitas

\begin{tabular}{c|c|c|c|c}
\hline \hline No & Variabel & Nilai Sig. & Batas Sig. & Keterangan \\
\hline 1 & Kompetensi SDM $\left(\mathrm{X}_{1}\right)$ & 0,209 & 0,05 & Tidak Terjadi Heterokedastisitas \\
\hline 2 & Sistem Pengendalian Intern $\left(\mathrm{X}_{2}\right)$ & 0,870 & 0,05 & Tidak Terjadi Heterokedastisitas \\
\hline
\end{tabular}

Sumber : Hasil Penelitian 2017 
Berdasarkan Tabel di atas untuk variabel Komptensi Sumber Daya Manusia (X1) sebesar 0,209 dengan nilai signifikansi lebih besar dari $0,05(0,209>0,05)$ maka dinyatakan data Komptensi Sumber Daya Manusia (X1)adalah homogen, selanjutnya, untuk variabel Sistem Pengendalian Intern (X2) diperoleh sebesar 0,870 dengan nilai signifikan lebih besar dari 0,05 yang bearti $(0,870>0,05)$ dan variabel ini berarti memiliki varians yang homogen.

\section{Analisis Regresi Berganda}

Analisis yang digunakan dalam penelitian ini adalah analisis regresi linier berganda dengan empat predictor yaitu Kompetensi Sumber Daya Manusia (X1), Sistem Pengendalian Intern (X2), Faktor Eksternal (X3), dan Kualitas Laporan Keuangan (Y). Model regresi ini dapat digunakan untuk mengetahui bentuk pengaruh kompetensi sumber daya manusia, sistem pengendalian intern, dan faktor eksternal terhadap kualitas laporan keuangan di Pemerintahan Daerah Kabupaten Pasaman Barat secara simultan dan parsial. Berdasarkan hasil perhitungan SPSS for windows release 24.0 diperoleh tabel analisis regresi sebagai berikut:

Tabel 5. Analisis Regresi

\begin{tabular}{|c|c|c|c|c|c|c|}
\hline \multirow{2}{*}{\multicolumn{2}{|c|}{ Model }} & \multicolumn{2}{|c|}{ Unstandardized Coefficients } & \multirow[t]{2}{*}{$\begin{array}{c}\text { Standardized } \\
\text { Coefficients } \\
\text { Beta }\end{array}$} & \multirow{2}{*}{$t$} & \multirow{2}{*}{ Sig. } \\
\hline & & B & Std. Error & & & \\
\hline \multirow[t]{3}{*}{1} & (Constant) & $-9,449$ & 8,342 & & $-1,133$ & 0,264 \\
\hline & Kompetensi SDM (X1) & 0,388 & 0,166 & 0,282 & 2,338 & 0,025 \\
\hline & Pengendalian Intern (X2) & 0,327 & 0,087 & 0,451 & 3,785 & 0,001 \\
\hline
\end{tabular}

Sumber : Hasil Penelitian 2017

Tabel di atas menunjukkan bahwa persamaan regresi berganda yang diperoleh dari hasil analisis, sebagai berikut :

$\mathrm{Y}=-9,449+0,388 \mathrm{X} 1+0,327 \mathrm{X} 2$

Model regresi tersebut mempunyai makna :

a. Konstanta : $-9,449$

Jika variabel kompetensi sumber daya manusia, sistem pengendalian intern, dan faktor eksternal dianggap konstan, maka rata-rata kualitas laporan keuangan sebesar $-9,449$.

b. Koefisien regresi X1 (Kompetensi Sumber Daya Manusia)

Dari perhitungan regresi berganda diperoleh nilai coefficients (b1) adalah 0,388. Hal ini berarti jika variabel kompetensi sumber daya manusiamengalami peningkatan sebesar 1 (satu) poin, sementara variabel sistem pengendalian intern dan faktor eksternal dianggap tetap maka akan menyebabkan kenaikan kualitas laporan keuangan sebesar 0,388 .

c. Koefisien regresi X2 (Sistem Pengendalian Intern)

Dari perhitungan regresi berganda diperoleh nilai coefficients (b2) adalah 0,327. Hal ini berarti jika variabel sistem pengendalian intern mengalami peningkatan sebesar 1 (satu) poin, sementara variabel kompetensi sumber daya manusia dan faktor eksternal dianggap tetap maka akan menyebabkan kenaikan kualitas laporan keuangan sebesar 0,327 .

\section{Uji Hipotesis}


a. Pengaruh Kompetensi Sumber Daya Manusia (X1) Terhadap Kualitas Laporan Keuangan di Pemerintahan Daerah Kabupaten Pasaman Barat (Y) secara signifikan.

Hasil penelitian ini menunjukkanbahwa kompetensi sumber daya manusia berpengaruh signifikan positifterhadap kualitas laporan keuangan daerah. Dengan demikian, jika kompetensi SDM bagian keuangan/akuntansi pada Pemerintahan Daerah Kabupaten Pasaman Barat baik, dalam artian SDM keuangan/akuntansi tersebut kompeten, maka kualitas laporan keuangan daerah yang dihasilkan pada Pemerintahan Daerah Kabupaten Pasaman Barat lebih baik. Ini juga disertai dengan keterampilan, pengetahuan, dan kemampuan yang dimiliki oleh responden dalam membuat laporan keuangan. Selain itu pengalaman kerja, kemampuan kerja dan pelatihan yang dimiliki oleh seorang pegawai pada Pemerintahan Daerah Kabupaten Pasaman Barat bisa mempengaruhi kualitas sumber daya manusia.

Hasil penelitian ini sejalan dengan teori yang dikemukakan oleh Bastian (2006) bahwa dengan adanya kompetensi staf akuntansi yang memadai memungkinkan terwujudnya laporan keuangan yang berkualitas sesuai dengan standar akuntansi pemerintah. Dilihat dari distribusi frekuensi, bahwa kompetensi SDM memiliki pengaruh terhadap kualitas laporan keuangan daerah hal ini dapat dibuktikan dari jawaban responden terhadap kuisioner yang disebarkan. Secara garis besar kompetensi SDM pada Pemerintahan Daerah Kabupaten Pasaman Baratsudah baik.

SDM merupakan human capital di dalam organisasi. Human capital merupakan pengetahuan, keterampilan, dan kemampuan seseorang yang dapat digunakan untuk menghasilkan layanan profesional dan economic rent. Human capital merupakan sumber inovasi dan gagasan. Karyawan yang dengan human capital tinggi lebih memungkinkan untuk memberikan layanan yang konsisten dan berkualitas tinggi (Sugeng dan Imam, 2000 dalam Sutaryo, 2011).

Dalam perkembangannya telah dilakukan beberapa penelitian terkait dengan kualitas laporan keuangan sektor publik baik di dalam maupun diluar negeri. Mengingat regulasi pemerintahan di Indonesia berbeda dengan negara lain, dan standar yang menjadi acuannya pun berbeda, memungkinkan didapat perbedaan hasil analisis yang cukup signifikan Xu, et al. (2003) meneliti faktor kunci dari kualitas akuntansi studi kasus di Australia. Hasil penelitiannya menyatakan Sumber daya manusia, sistem, organisasi, dan faktor eksternal merupakan faktor kritis menentukan kualitas akuntansi.

Choirunisah (2008) meneliti faktor-faktor yang mempengaruhi kualitas laporan keuangan yang dihasilkan sistem akuntansi instansi studi pada KPPN Malang. Hasil penelitiannya menyatakan kemampuan sumber daya manusia dan organisasi tim berpengaruh signifikan terhadap kualitas keuangan satuan kerja. 
Indriasari dan Nahartyo (2008) meneliti pengaruh kapasitas sumber daya manusia, pemanfaatan teknologi, dan pengendalian intern akuntansi terhadap nilai pelaporan keuangan pemerintah daerah (studi pada pemerintah kota palembang dan kabupaten ogan ilir). Hasil penelitiannya menyatakan bahwa kapasitas sumber daya manusia tidak mempengaruhi nilai pelaporan keuangan pemerintah daerah secara signifikan, sedangkan pemanfaatan teknologi informasi dan pengendalian intern akuntansi mempengaruhi nilai informasi pelaporan keuangan pemerintah daerah secara signifikan. Indriasari dan Nahartyo (2008) juga menyatakan bahwa kapasitas sumber daya manusia dan pemanfaatan teknologi informasi berpengaruh signifikan terhadap ketepatwaktuan pelaporan keuangan pemerintah daerah.

Winidyaningrum dan Rahmawati (2010) meneliti pengaruh sumber daya manusia dan informasi teknologi pemanfaatan kehandalan dan ketepatan waktu pelaporan keuangan pemerintah daerah dengan variabel intervening pengendalian internal akuntansi. Hasil penelitiannya menyatakan Sumber daya manusia berpengaruh positif signifikan terhadap keterandalan pelaporan keuangan pemerintah daerah, tetapi tidak signifikan terhadap ketepatwaktuan. PemanfaatanTI berpengaruh positif signifikan terhadap keterandalan pelaporan danketepatwaktuan.

Menurut Sulistyawati (2006) dalam Sutaryo (2011), SDM merupakan faktor yang berpengaruh terhadap kesiapan dan efektifitas implementasi sistem akuntansi keuangan daerah di lingkungan Pemerintah Kota Yogyakarta. MenurutGuy et al. (2002), kompetensi adalah pengetahuan dan keahlian yang diperlukan untuk menyelesaikan tugas. Kompetensi SDM yang memadai dari segi kuantitasdan kualitas akan meningkatkan kandungan nilai informasi dalam pelaporankeuangan Pemda.

Indriasari (2008) membuktikan dalam penelitian bahwa kapasitas sumber daya berpengaruh terhadap keterpautan dan keterandalan informasi laporan keuangan pemerintah daerah di Kota Palembang dan Kabupaten Ogan Hilir provinsi Sumatera Selatan. Bukti penelitian ini didukung oleh hasil penelitian Winidyaningrum dan Rahmawati (2010) yang menyatakan bahwa kapasitas sumber daya manusia berpengaruh terhadap keterandalan pelaporan keuangan pemerintah daerah, namun penelitian ini tidak berhasil membuktikan pengaruh kapaistas sumberdaya manusia terhadap ketepatwaktuan penyampaian dalam laporan keuangan.

b. Pengaruh Sistem Pengendalian Intern (X2)Terhadap Kualitas Laporan Keuangan di Pemerintahan Daerah Kabupaten Pasaman Barat (Y) secara signifikan

Sistem Pengendalian Intern Pemerintah (SPIP) dimaksudkan dengan tujuan memberikan keyakinan yang memadai agar tercapainya efektivitas dan efesiensi tujuan penyelenggaran pemerintah negara, keandalan pelaporan keuangan, pengamanan aset negara dan ketaatan 
terhadap peraturan perundang-undangan (PP No. 60 Tahun 2008). Dengan begitu, maka penyelenggaran keuangan atas kegiatan pemerintahan dapat mencapai pengelolaan yang efektifdan efisien.

Indikator untuk mengukur variabel ini didasarkan pada PP No. 60 Tahun 2008, yaitu lingkungan pengendalian, penilaian resiko, kegiatan pengendalian informasi dan komunikasi serta pemantauan. Berdasarkan data jawaban responden, rata-rata responden menjawab kadang-kadang untuk setiap indicator penilaian, yang artinya dari kelima unsur pengendalian tersebut masih belu dilaksanakan secara efektif. Berdasarkan hasil pengujian hipotesis dapat disimpulkan bahwa sistem pengendalian intern pemerintah berpengaruh terhadap kualitas laporan keuangan pemerintah daerah Kabupaten Pasaman Barat.

Semakin baik penerapan SPIP maka semakin baik pula kualitas laporan keuangan yang dihasilkan. Hasil penelitian ini sejalan dengan penelitian Yosefrinaldi (2013) yang menyatakan bahwa sistem pengendalian intern pemerintah berpengaruh positif terhadap kualitas laporan keuangan pemerintah daerah. Kemudian, Yudianta \&Erawati (2012) dengan hasil penelitiannya bahwa pengendalian intern akuntansi berpengaruh positif terhadap kualitas informasi akuntansi. Zuliarti (2012), pengendalian intern akuntansi berpengaruh positif signifikan terhadap keterandalan pelaporan keuangan pemerintah daerah.

Pengendalian intern merupakan bagian dari manajemen resiko yang harus dilaksanakan oleh setiap lembaga atau organisasi untuk mencapai tujuan lembaga atau organisasi. Penerapan pengendalian intern yang memadai akan memberikan keyakinan yang memadai atas kualitas atau keandalan laporan keuangan, serta akan meningkatkan kepercayaan stakeholders.

Sistem pengendalin intern meliputi berbagai alat manajemen yang bertujuan untuk mencapai berbagai tujuan yang luas. Tujuan tersebut yaitu menjamin kepatuhan terhadap hukum dan peraturan, menjamin keandalan laporan keuangan dan data keuangan, memfasilitasi efisiensi dan efektivitas operasi-operasi pemerintah. Dengan demikian, pengendalian intern merupakan fondasi good governance dan garis pertama pertahanan dalam melawan ketidakabsahan data dan informasi dalam penyusunan LKPD.

Masih ditemukannya penyimpangan dan kebocoran di dalam laporan keuangan oleh BPK, menunjukkan bahwa Laporan Keuangan Pemerintah Daerah belum memenuhi karakteristik/nilai informasi yang disyaratkan. Hasil audit yang dilakukan oleh BPK, BPK memberikan opini "tidak wajar dan/atau disclaimer" diantaranya disebabkan oleh kelemahan sistem pengendalian intern yang dimiliki oleh pemerintah daerah terkait. (Badan Pemeriksa Keuangan, 2011). Dalam penelitian terdahulu yang dilakukan oleh Nugraha dan Susanti(2010) menyatakan sistem pengendalian internal berpengaruh positif terhadap keandalan laporan keuangan. Penelitian lainnya juga dilakukan oleh Indriasari dan Nahartyo (2008) meneliti pengaruh kapasitas sumber daya manusia, 
pemanfaatan teknologi informasi, dan pengendalian intern akuntansi terhadap nilai informasi pelaporan keuangan pemerintah daerah (studi pada pemerintah kota palembang dan kabupaten ogan ilir). Hasil penelitiannya menyatakan bahwa kapasitas sumber daya manusia tidak mempengaruhi nilai pelaporan keuangan pemerintah daerah secara signifikan, sedangkan pemanfaatan teknologi informasi dan pengendalian intern akuntansi mempengaruhi nilai informasi pelaporan keuangan pemerintah daerah secara signifikan. Indriasari dan Nahartyo (2008) juga menyatakan bahwa kapasitas sumber daya manusia dan pemanfaatan teknologi informasi berpengaruh signifikan terhadap ketepatwaktuan pelaporan keuangan pemerintah daerah.

\section{E. KESIMPULAN}

Penelitian ini bertujuan untuk mengetahui pengaruh Kapasitas Sumber Daya Manusia, Pemanfaatan Teknologi Informasi Dan SistemPengendalian Intern Pemerintah Terhadap Kualitas Laporan Keuangan Pemerintah Daerah Kabupaten Pasaman Barat. Berdasarkan hasil penelitian, maka kesimpulan dari penelitian ini dapat diuraikan sebagai berikut:

1. Kompetensi sumber daya manusia berpengaruh secara signifikan terhadap kualitas laporan keuangan Pemerintah Daerah Kabupaten Pasaman Barat. Artinya bahwa semakin baik kompetensi sumber daya manusia maka semakin baik pula kualitas laporan keuangan pemerintah daerah yang dihasilkan.

2. Sistem Pengendalian Intern Pemerintah (SPIP) berpengaruh secara signifikan terhadap kualitas laporan keuangan Pemerintah Daerah Kabupaten Pasaman Barat. Artinya bahwa, semakin baik pelaksanaan unsur SPIP maka semakin baik pula kualitas laporan keuangan pemerintah daerah yang dihasilkan.

\section{F. SARAN}

Berdasarkan kesimpulan yang diperoleh dalam penelitian ini, penulis memberikan saran agar dapat dijadikan panduan atau acuan untuk penelitian selanjutnya, maka terdapat berapa saran yang dapat dipertimbangkan yaitu:

1. Dalam penelitian ini penulis hanya menggunakan populasi dan sampel yang sedikit yaitu sebanyak 44 orang pada Pemerintahan Daerah Kabupaten Pasaman Barat. Diharapkan dalam penelitian selanjutnya dapat menggunakan populasi dan sampel yang lebih besar misalnya disetiap PNS yang ada di daerah lain.

2. Diharapkan dalam penelitian selanjutnya menambahkan periode penelitian yang lebih panjang sehingga dapat menggali variabel-variabel lain yang dapat mempengaruhi Kualitas Laporan Keuangan.

3. Untuk peneliti selanjutnya semoga dapat menggali lebih dalam mengenai pengaruh Kompetensi Sumber Daya Manusia dan Sistem Pengendalian Intern terhadap Kualitas Laporan Keuangan Daerah. 


\section{DAFTAR PUSTAKA}

Badjuri, Achmad \& Elisa Trihapsari. 2004. "Audit Kinerja Pada Organisasi Sektor Publik. Pemerintah”. Fokus Ekonomi. STIE Stikubank Semarang. Semarang.

Bernhardsen, T. 2002. Geographic Information Systems: An Introduction, $3^{\text {rd }}$ Edition. John Wiley \& Sons Ltd. Canada.

Hutapea, Thoha. 2008. Kompetensi Plus. Jakarta: PT Gramedia Pustaka Utama

Sawyer, Dittenhofer, S. Cheiner, 2005. Internal Auditing, Buku Satu, Edisi Kelima, Jakarta : Salemba Empat.

Widodo, Joko. 2001. Good Governance: Telaah dari Dimensi: Akuntabilitas dan Kontrol Birokrasi pada Era Desentralisasi dan Otonomi Daerah. Insan Cedekia. Surabaya.

\section{Jurnal Penelitian}

Lillrank, Paul. 2003. "The quality of information", International Journal of Quality \& Reliability Management Vol. 20 No. 6 pp. 691-703.

Petrovits, et al. 2011. The Cause and Consequences Of Internal Control Problems in Nonprofit Organizations. The Accounting Review Vol. 86, No 1 : 325-357

Sugeng, Imam (2000). "Mengukur dan Mengelola Intellectual Capital." Jurnal Ekonomi dan Bisnis Indonesia Vol. 15 No. 2, hal 247-256.

Warisno. 2008. Faktor-faktor yang Mempengaruhi Kinerja Satuan Kerja Perangkat Daerah (SKPD) di Lingkungan Pemerintah Provinsi Jambi. Tesis. Pascasarjana Universitas Sumatera Utara. Medan.

Xu, Hongjiang, Jeretta H.N., G. Daryl Nord, Binshan Lin. 2003. "Key issue of accounting information quality management : Australian case studies". Industrial Mangaement \& Data System 103/7, 461- 470 